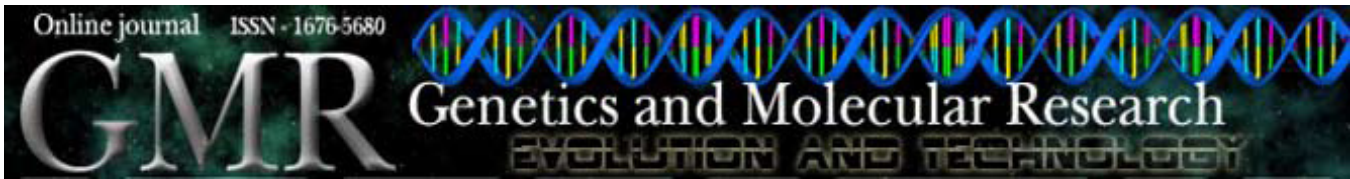

\title{
Anatomical alterations due to polyploidy in cassava, Manihot esculenta Crantz
}

\author{
Nagib M.A. Nassar, D. Graciano-Ribeiro, S.D.C. Fernandes \\ and P.C. Araujo
}

Departamento de Genética e Morfologia and Departamento de Botânica, Universidade de Brasília, Brasília, DF, Brasil

Corresponding author: N.M.A. Nassar

E-mail: nagnassa@rudah.com.br

Genet. Mol. Res. 7 (2): 276-283 (2008)

Received October 1, 2007

Accepted February 6, 2008

Published April 1, 2008

\begin{abstract}
Information on anatomical structure is needed by breeders working on improvement for drought tolerance. For studying the effect of polyploidy on cassava anatomy and its significance to tolerance to drought, we induced a polyploidy type of a selected clone (UnB 530) by applying an aqueous solution of $0.2 \%$ colchicine on lateral buds for a period of $12 \mathrm{~h}$. The stem identified as tetraploid was propagated to produce the whole plant. Free-hand cross-sections of the median portion between stem internodes were made. They were clarified using 50\% sodium hypochlorite solution, stained with $1 \%$ safranin-alcian blue, passed through an ethanol series and butyl acetate and mounted in synthetic resin. The tetraploid type showed more prismatic and druse crystals in the cortical parenchyma, and its pericycle fibers had thicker walls. The secondary xylem of tetraploid types was wider than diploid ones, having thinner walls and less starch.
\end{abstract}

Key words: Anatomy; Cassava; Diploid stems; Tetraploid stems 


\section{INTRODUCTION}

Cassava, Manihot esculenta Crantz, is the leading food and feed plant of the tropics. It is a major staple food for more than 800 million people in this part of the world. South America is responsible for about half of the world cassava production (Nassar, 1978a,b, 2006b). Brazil is its second largest producer and the first consumer all over the world (Nassar et al., 2002; FAO, 2005). Central Brazil is one of the four centers of diversity of Manihot species (Nassar, 1978c, 2003a, 2004). Cassava can feed both humans and animals, where both roots and leaves can be eaten. In some areas around the world, such as Northeast Brazil, more than $70 \%$ of calories consumed daily by the population comes from cassava (Nassar, 1999, 2002a,b). It is a potential crop to grow in semi-arid lands if a breeding method is carefully designed and followed (Nassar, 1995, 1999, 2002a,b, 2003c).

One of the approaches suggested to increase resistance to drought in some crops was to produce polyploidy based on observations of some researchers (Nassar, 1991, 1995, 2004, 2006a). However, information about the mechanism of resistance and anatomical basis still needs to be clarified. Scarce reports are published on this subject, but what is mentioned is that this resistance may result from anatomical alterations in the stem, root, and leaves of the plant (Stebbins, 1950). Since the writings of Stebbins, no experimental study has been done to document specifically these anatomical changes that may occur.

Few publications are available on Manihot anatomy. However, some on Euphorbiaceae could be reviewed. For example, Hayden and Brandt (1984) applied wood anatomy to the systematics of Neowawraea phyllanthoides, a rare and endangered member of Euphorbiaceae endemic to the Hawaiian Islands. Its wood is diffuse-porous, perforation plates are simple, imperforate tracheary elements are thin-walled septate fiber-tracheids, rays are heterocellular and crystalliferous, and axial xylem parenchyma is restricted to a few scanty paratracheal and terminal cells.

A comparison of anatomical features of leaves between diploid and natural tetraploid species of Triticum was published by Jellings and Leech (1984). They reported anatomical variation in first leaves of Triticum. Kaminski et al. (1990) and Pyke et al. (1990) repeated the same observation in Aegilops species. Leaf anatomy in Lolium diploid and tetraploid types was studied by Sugiyama (2005) who reported a difference in mesophyll tissue in tetraploid type.

These few reports on anatomy of polyploidy were in plants where only leaves were treated. Our research reports the first study about stem anatomy in induced tetraploid type. We describe here different anatomical features attributed to polyploidy in cassava clone UnB 530.

\section{MATERIAL AND METHODS}

We induced a polyploidy type of a selected clone (UnB 530) by applying an aqueous solution of $0.2 \%$ colchicine to lateral buds for a period of $12 \mathrm{~h}$. The stem identified as tetraploid was propagated to produce the whole plant (Nassar, 2003b, 2004). Diploid and tetraploid mature stems of cassava clone UnB 530, grown at the biological station of the Universidade de Brasília, were sampled from different plants. Samples were fixed in $70 \%$ formaldehyde acetic acid and alcohol (Johansen, 1940) and preserved in 70\% ethanol.

Free-hand cross-sections, using an R. Jung Heidelberg 2686 microtome, were made of the median portion between stem internodes. They were clarified using 50\% sodium hypochlorite solution (Kraus and Arduin, 1997), stained with 1\% safranin-alcian blue (Luque et al., 1996), passed 
through ethanol series and butyl acetate and mounted in synthetic resin (Paiva et al., 2006).

Photomicrographs were taken using a Leica DC 1000 light photomicroscope and IMD 50 software.

\section{RESULTS}

Stems of both types were studied to show alterations in periphery (Figure 1A-F), vascular (Figure 2A-F) and medullary (Figure 3A-F) tissues. Stems of both types were seen to be circular or cylindrical in cross-sections (Figure 1A,D), and they showed secondary growth with phellogen and vascular cambium (Figure 1A,B,D,E). Vascular cambium is easily viewed with many cell layers undergoing differentiation (Figure 1B). Stem tissues from periphery to medulla are epidermis interrupted by periderm, different quantity of phellem layers, and there are some lenticels (Figure 1A,D). Cortical parenchyma showed idioblasts (Figure 1C,F) - druse and prismatic crystals - and isolated laticifers. Angular collenchyma with up to 5 cell layers is followed by 1-cell layer of parenchyma holding those crystals and starch, which forms a starch sheath (Figure 1C,F). Pericyclic fibers form an interrupted cylinder having differences in cell wall thickness (Figure 1C,F).

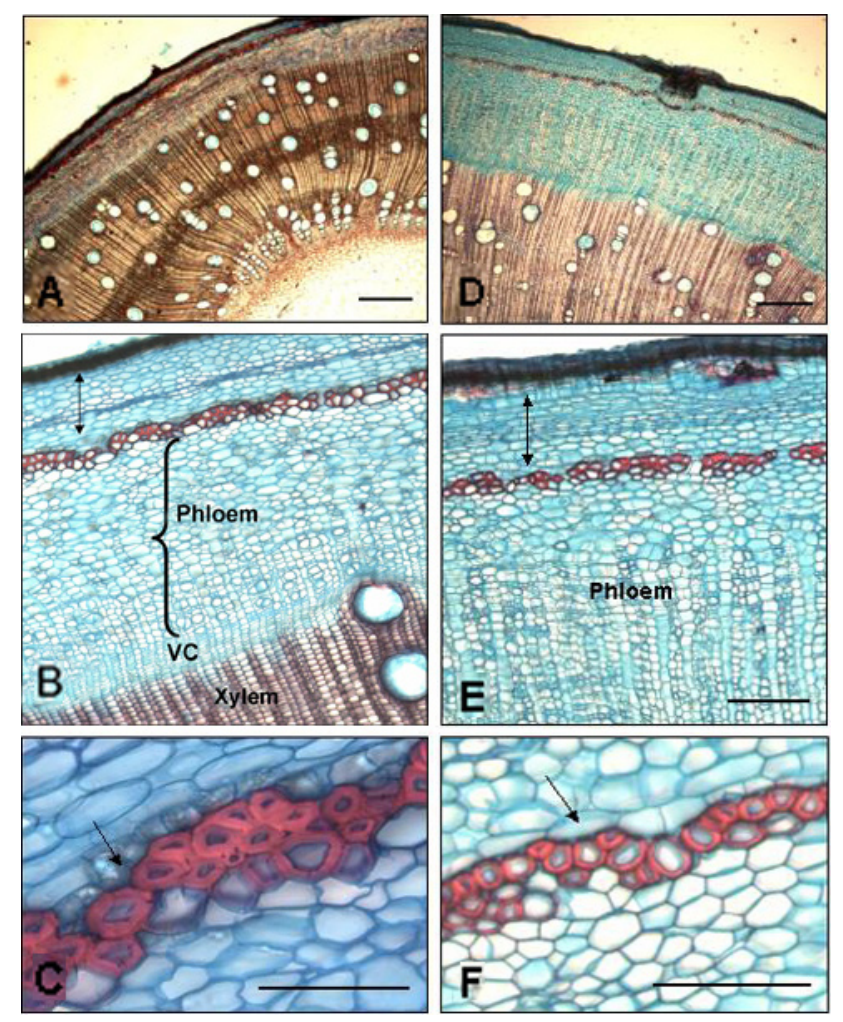

Figures 1. Diploid (A-C) and tetraploid (D-F) stems of transverse sections of clone 530. A. Stem great view. B. Cortex detail (double arrow), secondary phloem, vascular cambium (VC) and secondary xylem. C. Starch sheath detail (arrow) with crystals and thicked cell wall pericyclic fibers. D. Stem great view, showing bigger diameter. E. Cortex detail (double arrow) and secondary phloem; these areas are more developed. F. Starch sheath detail (arrow) with crystals and thinner cell wall pericyclic fibers; these cells are smaller. Bar $=0.1 \mathrm{~mm}$ for all panels. 
Secondary phloem is represented by sieve elements, companion cells and laticifers in a row of small groups between other cells, and phloem parenchyma rays are continuous with those in secondary xylem (Figure 2A-F). Secondary xylem has vessel elements, fibers, tracheids, radial parenchyma, and vasicentric axial or scarce paratracheal parenchyma (Figure 2A-F). There are solitary vessels and vessel groupings, and they may have tyloses (Figure 2A,D). Radial parenchyma cells are rectangular in a row (Figure 2A,D). Xylem fibers attract attention because of their little lignified walls, large cell lume and rectangular shape, similar to parenchyma cells (Figure 2B,E). In addition to these structures, in secondary xylem there are also denser tissue rows, reminiscent of secondary growth rings (Figure 2A). Primary xylem showed protoxylem and metaxylem elements enveloped by parenchyma cells (Figure 2C,F).
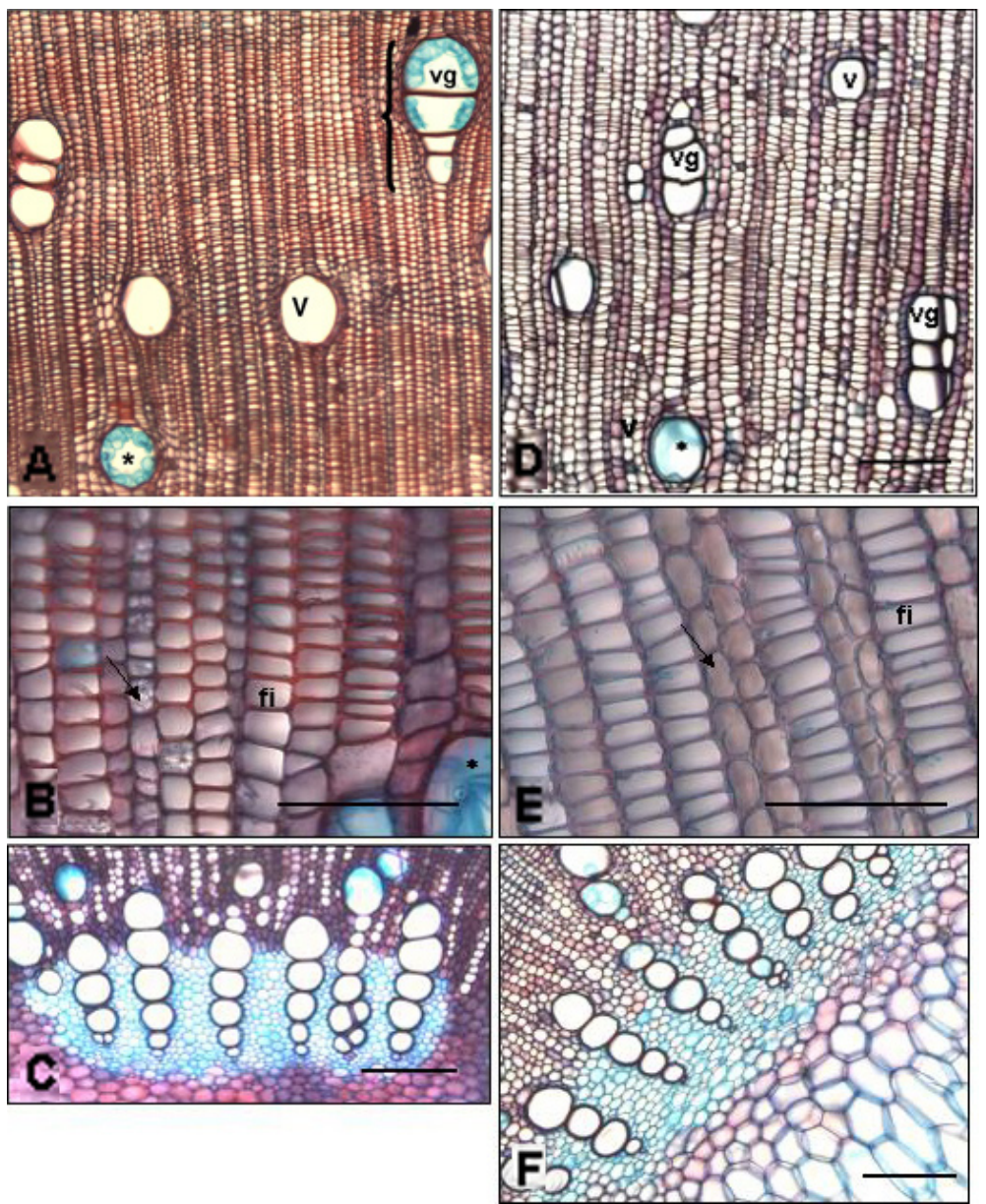

Figures 2. Diploid (A-C) and tetraploid (D-F) stems of transverse sections of clone 530. A. Secondary xylem detail, showing solitary (v) and vessel grouping (vg) with tyloses (asterisk). B. Secondary xylem detail, thicked cell wall fibers (fi) and parenchyma cells with starch (arrow). C. Primary xylem detail. D. Secondary xylem detail, showing more vessel grouping (vg), and tyloses (asterisk). E. Secondary xylem detail, thinner cell wall fibers (fi) and parenchyma cells with no starch (arrow); these cells are bigger. F. Primary xylem detail. Bar $=0.1 \mathrm{~mm}$ for all panels. 
The medulla was seen to be divided into two different areas according to cell shape and content and number of layers (Figure 3B,C). The peripheral area close to primary xylem has isodiametric cells, while central area has polygonal cells with 5 or 6 sides; cell content and number of layers are different between stem ploidy (Figure 3B,C,E,F).
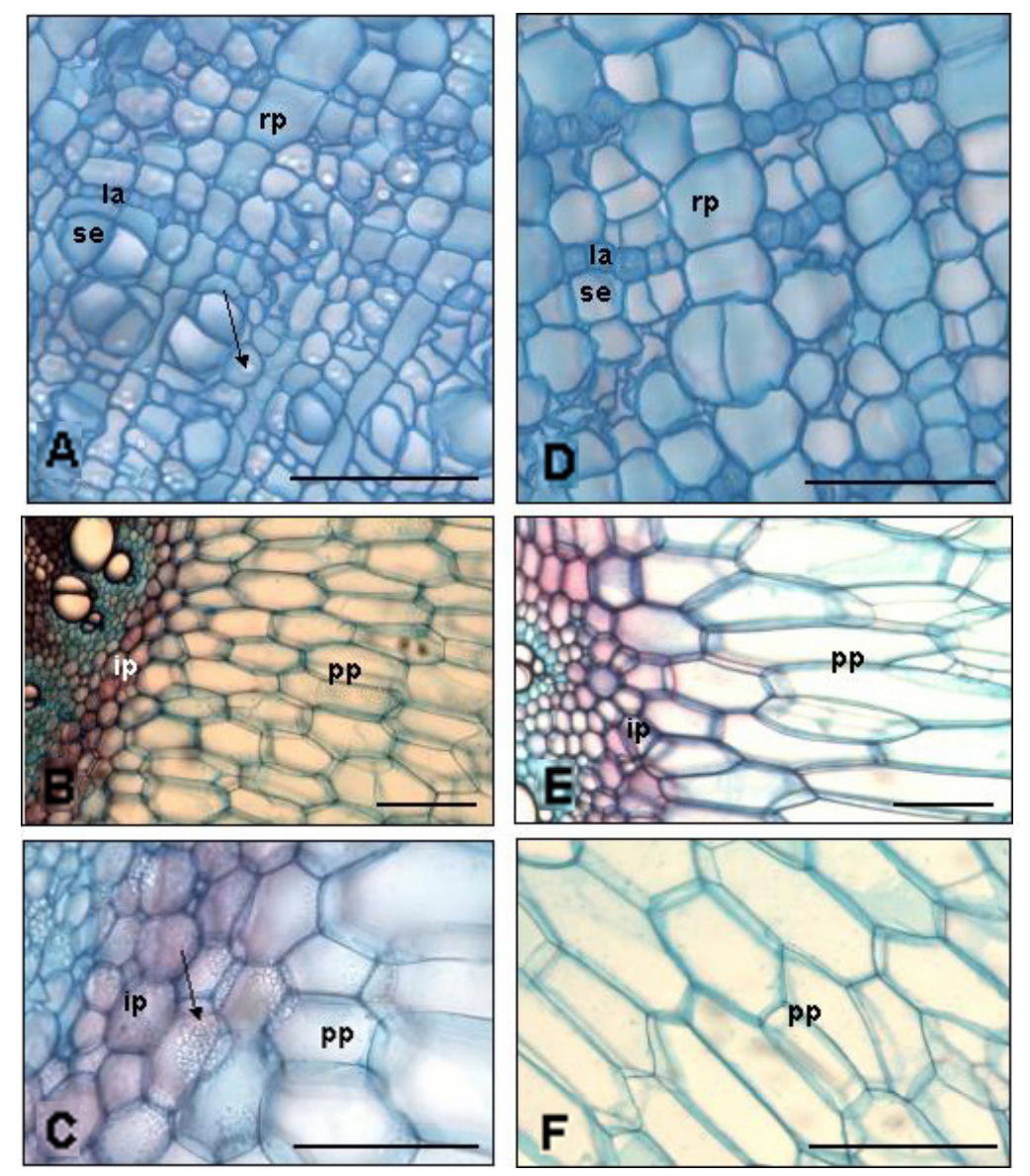

Figures 3. Diploid (A-C) and tetraploid (D-F) stems of transverse sections of clone 530. A. Secondary phloem detail, laticifers (la), radial parenchyma (rp), sieve elements (se) and starch (arrow). B. Medulla with isodiametric (ip) and polygonal (pp) parenchyma cells. C. Isodiametric (ip) and polygonal (pp) parenchyma cells, with starch (arrow). D. Secondary phloem detail, laticifers (la), radial parenchyma (rp), sieve elements (se); these cells are bigger and there is no starch inside. E. Medulla with isodiametric (ip) and polygonal (pp) parenchyma cells, they are longer and narrower. F. Polygonal (pp) parenchyma cells; they are longer and narrower and there is no starch inside. Bar $=0.1 \mathrm{~mm}$ for all panels.

The differences between diploid and tetraploid types can be noted in cortex as follows: tetraploid types showed more prismatic and druse crystals in cortical parenchyma, and pericyclic fibers have thicker cell walls. However, greater differences between these types are found in primary and secondary xylem and medulla. 
In secondary xylem, tetraploid type radial parenchyma cells are wider, with thinner walls and little starch; there are more vessel groupings than solitary ones, with little tylose inside elements (Figure 2D) and no starch in primary xylem. Diploid type has radial parenchyma cells in secondary xylem being narrower with thicker walls and much starch; there are more solitary vessel elements than groupings, normally with tylose inside (Figure 2A) and starch in primary xylem.

Tetraploid peripheral medulla has 1-2 layers of isodiametric parenchyma cells without starch (Figure 3E), while diploid type has up to 7 layers of cells with starch (Figure 3B). Tetraploid type has polygonal parenchyma cells in the central medulla, and they are narrower and longer, with little cytoplasm content (Figure 3F); diploid type has these cells wider and shorter, with druses, starch and few prismatic crystals (Figure 3C).

In a quantitative way, the tetraploid type has secondary vascular tissues - phloem and xylem - that are more developed than in diploid type.

\section{DISCUSSION}

Agronomic practices require full attention in relation to different kinds of plants with different kinds of handlings and structure, since the vegetal body is related to those practices in a dynamic way (Silva-Lima et al., 2005).

To study the effect of ploidy level on leaf anatomy, Jellings and Leech (1984) studied the variation in over 20 leaf characters including morphological, anatomical and cellular features in nine Triticum genotypes at three levels of ploidy (diploid, tetraploid and hexaploid), where the character measured most strongly influenced by ploidy level was cell size. Since cell size is strongly influenced by nuclear genome size, the hexaploid wheats have much larger cells than the diploid ones.

Stebbins (1971) and later Sugiyama (2005) emphasized the increase of organ size of autotetraploid populations in two species of Lolium and concluded that organ size is increased by greater cell ploidy, but the mechanism of this effect is poorly understood. Cavalier-Smith (1985) discussed the significance of the proportional increase in cell volume with increase in DNA content. They attributed it to balanced cell growth through maintenance of a constant ratio between the nuclear volume devoted to transcription and the cytoplasmic volume devoted to protein synthesis. This increase in cell volume with increase in DNA content was observed in secondary xylem radial and vasicentric axial parenchyma cells, and radial parenchyma and sieve elements of secondary phloem; these cells are wider in the tetraploid type than in the diploid one.

Anatomy knowledge is essential when vegetative propagation is used to identify important structural features necessary for propagation success (Silva-Lima et al., 2005). In the stake process, in perennial xylem, adventitious roots are formed from meristematic cells in the secondary phloem, radial parenchyma or vascular cambium (Hartmann et al., 1997). Since tetraploid type has secondary vascular tissues - phloem and xylem - more developed than in the diploid type, it is possible that the number of adventitious roots will be greater in the tetraploid one, but no experiments have been conducted yet to verify this.

According to Dehgan (1982), there are numerous fibers and laticifers in 49 species of Jatropha (Euphorbiaceae) studied. Fibers are generally found in the peripheral region of the ground tissue, but are most common in the interfasicular regions. Clone 530 showed a fiber distribution similar to that found by Dehgan (1982), but laticifers were restricted to cortical parenchyma and secondary phloem. 
Fibers are composed of lignin. Alves de Brito et al. (1999) found that lignified tissues, in leaves and stems, can increase according to plant growth. Moreover, cultivars from the same species can have different lignin increments (Akin, 1989; Silva-Lima et al., 2001a,b; Brito and Rodella, 2002). Our diploid type showed different lignin content and different cell wall thickness, while the tetraploid sample had a thicker cell wall.

Cultivars from the same species can also show differences in density, compaction and thickness of parenchyma cells, which results in different levels of resistance to microorganisms. Consequently, cultivars with more parenchyma cells show more resistance (Philip et al., 1991). Natural compaction of stem inner tissues is a physical factor that promotes resistance to insect (Noris and Kogan, 1980). Accordingly, tetraploid types show more resistance than diploid ones.

The structures described above are clearly responsible for what is reported about sturdier stems of tetraploid types. We can conclude that the anatomical alterations induced by polyploidy may confer upon tetraploid plant tolerance to drought. Moreover, the large number of vessel groupings in the tetraploid type may maintain a larger quantity of water than in case of fewer ones in diploid plants.

\section{ACKNOWLEDGMENTS}

Research supported by the National Council of Scientific Research (CNPq), Brasília.

\section{REFERENCES}

Akin DE (1989). Histological and physical factors affecting digestibility of forages. Agron. J. 81: 17-25.

Alves de Brito CJFA, Rodella RA, Deschamps FC and Alquini Y (1999). Anatomia quantitativa e degradação in vitro de cultivares de capim-elefante (Pennisetum purpureum Schum) (Poaceae). Arq. Biol. Tecnol. 40: 661-671.

Brito CJFA and Rodella RA (2002). Caracterização morfoanatômica da folha e do caule de Brachiaria brizantha (Hochst. ex A. Rich.) Stapf e B. humidicola (Rendle) Schweick (Poaceae). Rev. Bras. Bot. 25: 221-228.

Cavalier-Smith T (1985). Cell volume and the evolution of eukaryotic genome size. In: The evolution of genome size (Cavalier-Smith T, ed.). John Wiley and Sons, Chichester, 105-184.

Dehgan B (1982). Comparative anatomy of the petiole and infrageneric relationships in Jatropha (Euphorbiaceae). Am. J. Bot. 69: 1283-1295.

FAO (2005). Production yearbook. FAO, Rome.

Hartmann HT, Kester DE, Davies FT and Geneve RL (1997). Plant propagation: principles and practices. Englewood Clipps/Prentice Hall, New York.

Hayden WJ and Brandt DS (1984). Wood anatomy and relationships of Neowawraea (Euphorbiaceae). Syst. Bot. 9: 458-466.

Jellings AJ and Leech RM (1984). Anatomical variation in first leaves of nine Triticum genotypes and its relationship to photosynthetic capacity. New Phytol. 96: 371-382.

Johansen DA (1940). Plant microtechnique. 3rd edn. Paul B. Hoeber Inc., New York.

Kaminski A, Austin RB, Ford MA and Morgan CL (1990). Flag leaf anatomy of Triticum and Aegilops species in relation to photosynthetic rate. Ann. Bot. 66: 359-365.

Kraus JE and Arduin M (1997). Manual básico de métodos em morfologia vegetal. EDUR, Seropédica, Rio de Janeiro.

Luque R, Sousa HC and Kraus JE (1996). Métodos de coloração de Roeser (1972) - modificado - e Kropp (1972) visando a substituição do azul de astra por azul de alcião 8GS ou 8GX. Acta Bot. Bras. 10: 199-212.

Nassar NMA (1978a). Conservation of the genetic resources of cassava (Manihot esculenta Crantz): Determination of wild species localities with emphasis on probable origin. Econ. Bot. 32: 311-320.

Nassar NMA (1978b). Some further species of Manihot with potential value to cassava breeding. Can. J. Plant Sci. 58: 915-916.

Nassar NMA (1978c). Wild Manihot species of central Brazil for cassava breeding. Can. J. Plant Sci. 58: 257-261.

Nassar NMA (1991). Production of triploid cassava, Manihot esculeta Grants, by hybrid diploid gametes. Field Crops Res. 13: 173-182.

Nassar NMA (1995). Development of cassava interspecific hybrids for savanna (cerrado) conditions. J. Root Crops 22: 9-17. 
Nassar NMA (1999). Cassava, Manihot esculenta Crantz genetic resources: their collection, evaluation and manipulation. Adv. Agron. 69: 179-230.

Nassar NMA (2002a). Cassava, Manihot esculenta Crantz, genetic resources: origin of the crop, its evolution and relationships with wild relatives. Genet. Mol. Res. 1: 298-305.

Nassar NMA (2002b). Cassava, Manihot esculenta Crantz, genetic resources: the origin of the crop, its evolution and relationships with wild relatives. Gene Conserve 2: 31-43.

Nassar NMA (2003a). Cassava, Manihot esculenta Crantz genetic resources: IV. Anatomy of a diversity center. Genet. Mol. Biol. 2: 214-222.

Nassar NMA (2003b). Fertility and chimera induction in cassava, Manihot esculenta Crantz interspecific hybrids. Gene Conserve 9: 118-125.

Nassar NMA (2003c). Gene flow between cassava Manihot esculenta Crantz and its wild relatives. Genet. Mol. Res. 2: 334-347.

Nassar NMA (2004). Polyploidy, chimera and fertility of interspecific cassava (Manihot esculenta Crantz) hybrids. Indian J. Genet. Plant Breed. 64: 132-133.

Nassar NMA (2006a). The synthesis of a new cassava-derived species Manihot vieiri Nassar. Genet. Mol. Res. 5: 536-541.

Nassar NMA (2006b). Cassava in South America, Brazil's contribution and the lesson to be learned from India. Genet. Mol. Res. 5: 688-695.

Nassar NMA, Elkholy H and Eltantawy A (2002). Cassava productivity worldwide: An overview. Ceres 49: 369-381.

Noris DM and Kogan M (1980). Biochemical and morphological bases of resistance. In: Breeding plants resistance to insects. (Maxwell FG and Jennings PR, eds.). Wiley Interscience Publication, New York, 23-61.

Paiva JGA, Fank-de-Carvalho SM, Magalhães MP and Graciano-Ribeiro D (2006). Verniz vitral incolor 500 ${ }^{\circledR}$ : uma alternativa de meio de montagem economicamente viável. Acta Bot. Bras. 20: 257-264.

Philip T, Govindaiah C, Sengup AK, Naik VN, et al. (1991). Anatomical nature of resistance in mulberry genotypes against Cerotelium fici causing leaf rust. Indian Phytopathol. 44: 249-251.

Pyke KA, Jellings AJ and Leech RM (1990). Variation in mesophyll cell number and size in wheat leaves. Ann. Bot. 65: 679-683.

Silva-Lima LM, Alquini Y, Brito CJF and Deschamps FC (2001a). Degradação ruminal dos tecidos vegetais e composição bromatológica de cultivares de Axonopus scoparius (Flüegge) Kuhlm. e Axonopus fissifolius (Raddi) Kuhlm. Cienc. Rural 31: 509-515.

Silva-Lima LM, Alquini Y, Brito CJF and Deschamps FC (2001b). Área de tecidos de folhas e caules de Axonopus scoparius (Flüegge) Kuhlm. e Axonopus fissifolius (Raddi) Kuhlm. Cienc. Rural 31: 425-430.

Silva-Lima LM, Alquini Y and Cavallet VJ (2005). Inter-relações entre a anatomia vegetal e a produção vegetal. Acta Bot. Bras. 19: 183-194.

Stebbins GL (1950). Variation and evolution in plants. Columbia University Press, New York.

Stebbins GL (1971). Chromosomal evolution in higher plants. Addison-Wesley, London.

Sugiyama S (2005). Polyploidy and cellular mechanisms changing leaf size: comparison of diploid and autotetraploid populations in two species of Lolium. Ann. Bot 96: 931-938. 